\title{
'It's more like peeling away the layers of the onion, than putting a container around the onion': A Conversation with Lee Worley
}

(Via Zoom, 30 July 2020)

Lee Worley is Professor Emerita of Performance and Contemplative Education, Naropa University. Under the guidance of its founder, Chögyam Trungpa Rinpoche, she began studying Mudra Space Awareness in 1974 and is one of a handful of authorized Mudra teachers. This work formed the basis of her Contemplative Performance training method. A practioner of Vajrayana Buddhism, she is one of four 'Mitras' (Spiritual Friends) in the Buddhist sangha of Nalandabodhi directed by Dzogchen Ponlop Rinpoche. Mitra Lee has written two books: Coming From Nothing: the Sacred Art of Acting (2001) and Teaching Presence: Field Notes for Players (2018).

LEE WORLEY: Am I still frozen?

ANTON KRUEGER: ...every now and then there's a little bit of a gap where it freezes ...It's okay, we can use the pause to take a moment every now and then...

LEE: Yeah, okay.

ANTON: Fantastic, I really enjoyed going through your book again, Coming From Nothing: The Sacred Art of Acting (2001). On every page I found something amazing and it feels as though I was just rewriting the whole book in the notes I was taking. You talk about things that make so much sense - presence, spontaneity, basic goodness, stillness...How do we prevent these things from staying as reified concepts to archive and just store away? How does one keep it alive?

LEE: That certainly would be an article in itself. If you take the concept of mindfulness, and see what's happened to that over the course of five years, it's all stored away somewhere. People today just use the word and think they're mindful. So I don't know the answer.

I know it for myself, and that is I have a meditation practice. And it keeps me honest. I mean, when you sit down and have nothing to do except try to get out of 
the way, when you're taking a look at your mind...well, it's humbling... (laughs)

ANTON: Do you have a daily meditation practice?

LEE: Oh, yes, I do. And with this blessing of a pandemic, I actually have a pretty strong one because I don't really have that much else that's on a tight schedule. So I'm able to practice daily and it really does help.

ANTON: We're all a bit on retreat now, aren't we? Everybody has to slow down. That's been true for me as well. I have a teacher from Ireland, Dónal Creedon, who I usually see only once a year in December, but now he has a daily morning sitting session and I see him every day. It's pretty amazing.

LEE: That's wonderful. It's the blessings as well as the pain.

ANTON: Your approach to performance comes from Dharma Arts and Buddhism, whereas mindfulness might be seen as a slightly more secular concept. What do you understand mindfulness to be? Or do you see it as something different from meditation, for example?
LEE: What I understand from my training in Buddhism is mindfulness is the ability to stay on task. So it's no big deal. Everybody should have mindfulness, it's a basic human ability.

ANTON: I like that - staying on task. I also like recognising the 'ordinariness' of it. There's a Zen connotation of the 'ordinary mind' as something basic, isn't there? I did an interview ${ }^{i}$ a few days ago with $\mathrm{Al}$ Wunder, who's known as the 'father of improvisation in Australia' and his company is called Theatre of the Ordinary.

There were actually quite a few resonances between his approach and what you write in your book. For example, you talk about 'intelligent self-regulation' as something your course wants to cultivate. Al used the term 'self-teachers' - he tries to teach people, ultimately, to teach themselves, to become their own witnesses. Both of these terms relate to becoming aware of the processes of one's own mind.

Anyhow, but to get back to the idea of 'ordinariness'; what do you understand by it? 
LEE: Well, in the terminology of Buddhism, as I understand it, 'ordinary' doesn't mean humdrum.

ANTON: Right, the usual usage has a negative connotation.

LEE: Yeah, like, kind of boring. But in the sense of the word, as I understand it from the Tibetan Buddhist side, 'ordinary mind' is mind before it's been overlaid with all of the misconceptions and misunderstandings, habitual patterning and confusions that we adopt or have adopted or have had laid upon us, either by society, or families, or civilizations. If you happen to be Buddhist, this also includes past incarnations. In this sense, 'ordinary' would be a stripping away, which I think is true in improvisation also - there's a 'stripping away', and just letting be what is.

And that's hard in improvisation where the biggest idea is, 'I want the audience to be engaged or to like me or like it'....There's a kind of extension beyond oneself. So I think that in terms of Dharma, a good ground for training as an improviser would be a practice that is inviting one to strip away a lot of this external stuff and get back to 'ordinary mind', so that what one is improvising is the honesty of oneself, rather than the overlays of other people's impositions and the desire to be liked or the desire to please or make money or whatever. Then you can say the truth. Cause what's the point if you're not trying to tell the truth?

ANTON: I guess that also links with the idea of basic human goodness that the Dalai Lama often talks about. The idea that there is something good in the ordinary and that we can trust it. That we can trust the emergence of what's at heart, rather than be suspicious of it, or think we need to be something different. In the Christian tradition, I suppose, there's a sense that we're born into sin, but this idea of 'ordinariness' is that, actually, we're okay. The basic Buddha nature is there, and the other stuff is the artificial imposition.

LEE: I think it's a little less 'personoriented', but you're right, it's that things are good. And that doesn't exclude people.

ANTON: On your Mudra course, l'd written down something you cited from the Zen tradition: 'Everybody's perfect, but we can all use a little help'. I like that. In your book you also say that 'basic goodness is not about goodness versus badness'. Could you clarify what you mean by that? 
LEE: If you use the analogy of painting, you know, you could have red and black colours as good and bad, but the canvas itself is good. 'Basic' is the important word, because good and bad are not basic, they're duality.

ANTON: Okay, so the canvas is like space? Space is the thing?

LEE: Of course.

ANTON: Can we talk a bit about the word 'performance'? There are so many different understandings of it. You've got the whole field of Performance Studies that Richard Schechner started up. In the corporate world 'performance' has taken on a connotation of 'being the best you can be', in the way a car can 'perform well'. I mean, I'm not saying that's necessarily a terrible thing. Then there's also another understanding of 'performance' as some kind of trickery or pretence: to pretend to be something that you're not. What does the word mean to you?

\section{LEE: To me personally?}

ANTON: Sure, and also to the school of contemplative studies that you've created, or come from.
LEE: I use 'performance' rather than 'acting', because of just what you're saying: 'acting' seems to be stained with an idea that it's phony. I think of performance as more all-encompassing. If you get out of bed in the morning, you're performing. Not that you're lying, or artificial.

In your email inviting me to this conversation, you wrote something about the difference between mudra and masks. I think of masks as something that one puts on to cover up, while mudra is more a symbolic statement of the way things are. So we have a phrase we use to practise, that 'you are your own mudra'. That doesn't mean you are your own phony. It means: this is who you are - you symbolize yourself. What choice do you have really?

So, performance to me is more like the idea of authentically being who you are, rather than trying to create some kind of deception or magic trick or mask. One could argue that masks are not covering, but simply proclaiming aspects of things that are larger or more powerful or spiritual than the little self of the human; but I don't think that's how we use it very often, except maybe in ritual theatre. 
ANTON: Have you read Keith Johnstone's writing on masks in Impro (1979)?

LEE: A long time ago.

ANTON: It's pretty way out. When I read it, I was like, wow, this is wild. He sees the mask as possessing the wearer. It has its own energy and its own identity. It doesn't matter who wears the mask, it takes them over. It's almost like a deity energy or spiritual entity.

LEE: Well, I certainly think that's a way of seeing it in Japanese Noh drama, and in a lot of Asian performance. And I find it too. Don't you find if you're wearing a mask that you can kind of sort of relax a little bit and allow the mask to be what's happening?

ANTON: I guess even in a regular ritual, where you might be wearing a formal suit to a wedding or something like that, you could relax behind the rules and regulations of the process. If you're a newcomer or you don't know the ritual, or you have an ill-fitting suit you'd be nervous. Like, the mask hasn't possessed you yet.

In your book you also talk about the shamanistic roots of theatre, and say how stage fright is a real thing because you're realising that what you're doing has real power. Knowing that you can do something quite powerful creates a legitimate excitement or energy. I like this way of thinking, not to just dismiss 'stage fright' as something trivial to be overcome, but to honour it because of the importance of the ritual.

What I was thinking now about the mask and mudra was the line from a Mahamudra text which says 'Things are not as they appear. Nor are they otherwise'. Have you heard that one?

LEE: (laughs) A thousand times....

ANTON: There's that dreamlike awareness that reality is in our perception, not objectively the same for all, and yet, this perception of how things are is also $100 \%$ real..

LEE: That's the same as 'You are your own mudra'. You are the sign or symbol of yourself.

ANTON: I did have another note here about 'basic goodness'. For example, if we look at He Who Should Not Be Named who's running your country at the moment LEE: "Running" is a euphemism...(laughs) 
ANTON: (Laughter) ... I had the thought that he actually improvises a lot, doesn't he? He doesn't stick to the script, he speaks off the cuff. He's improvising...But is that also basic goodness, just sort of saying whatever comes to mind? Is he coming from a place of basic goodness?

LEE: Well, we don't know where he's coming from, do we? Can one say that of anyone, that you know where they're coming from?

ANTON: I suppose Trump does have a script, the 'billionaire' script, which has interests in an elite group. Perhaps that's his text, and he's not improvising at all.

LEE: I wouldn't know, all I can see is someone with a very monkey mind.

ANTON: Right, it's quite short term, grabs at whatever is interesting.

LEE: Most people do.

ANTON: Since l've now stumbled onto the territory of the 'political'. What do you think is the contemplative theatre approach to the political landscape? How does it sit with the mantra of 'the personal is political'? l've never really understood the expression. They don't seem the same thing at all, more like opposites. The 'political' is a kind of abstracted thing, and the personal is here, embodied, subjective. Contemplative work is deeply personal, but, of course, also interconnected to the environment, other people, ecology. I'm still not quite sure how a contemplative approach fits with the political. Do you think there's a place for contemplative theatre in the political upheavals that are playing out at the moment?

LEE: I often go back to one thing that my teacher, Trungpa Rinpoche, once said, which really struck me. He said that theatre seems to work best when the community that it's serving is a community in accord. Politics seems to me to be about discord and disagreement. I don't really know what the word 'politics' or 'political' means, but I get the feeling that it's kind of antagonistic. Not to say that theatre should be nice or play into the belief system of its audience, but if it is an audience that's in accord about something, then the theatre can speak to the places where it needs to wake up or where it needs to alter. Then it's working with its population, rather than trying to appease both sides. What he said was that theatre works best when it's 
talking to an audience that has an understanding of community in common, rather than being in argument with itself.

ANTON: Originally, the word politics would be from 'polis', so its meaning would have something to do with the communal. That goes back to the Greek city states where there was a unity - a city, one thing. It didn't have this diffuse, multi-national emotional drift. I must say, I find it quite distressing, the pull and push of the 'If you're not for us, you're against us' type thinking. That you become my enemy if you don't wave a banner in my parade. Can't one respond to different, specific contexts? Where's the middle ground?

LEE: Yeah. It's very old-fashioned thinking.

ANTON: Another thing I often think about in terms of improvisation is this idea of 'freedom and control' and trying to balance these in some way. What can we control? There's a feeling of wanting to allow freedom and playfulness and exploration and discovery; but where does discipline come into it? Or is there something we can control to allow more freedom in improvisation, as well as in mindfulness?
LEE: What is it that you want to control? What do you need to control? I didn't get that...

ANTON: I'm just sort of riffing here on the idea of the balance between freedom and control in improvisation and also in mindfulness. (And in life, I suppose.) Maybe we don't need this duality of 'freedom and control', but it comes up for me sometimes in meditation. Some teachers talk about controlling the mind in some way, but l've noticed that Western teachers avoid talking about control because it carries implications of maybe trying to dominate or -

\section{LEE: Oppress.}

ANTON: Exactly. There's a negative association of trying to force reality to conform to what I want it to be, and being inflexible or rigid in some way. And yet, don't we want to master our minds, and our craft? Isn't that a kind of control, to not just be swept about, helplessly...?

LEE: The terminology seems to get in the way. My understanding of why we meditate is not to master our mind so much as to allow our mind to be without all this conceptual overlay that didn't originate with 
who we are. So it's more like peeling away the layers of the onion than it is putting a container around the onion. That's my understanding, at least from a Vajrayana perspective.

Yes, on the basic level of the Four Noble Truths and the foundation, you need boundaries. Yes, you need control - you need to sit down, you need to have some kind of object that you're focusing on so that, you know, one's mind can come back to nowness from wandering in thinking and so on. But ultimately, that's only so that you can begin to get a sense of the problem and the project of letting go.

In terms of improvisation, my sense is that the control is the form. Everything has a beginning, middle and end - that's a control. If a human being is speaking, he'll be speaking a language - that's a control. If you have an idea that you're criticizing the government, that's a control. If you listen and speak, and you know you're not supposed to do it at the same time, that's a control. So there are plenty of controls. The question is within those controls, are you able to find the openness of freedom?

One control that I used to like very much when I was working with improv was to know the beginning and to know the ending, and then let the middle unfold itself. That's a nice control in my mind, because you know where you're going so you can let go of that problem and simply let it play out. And I see that as kind of a metaphor for life, actually.

ANTON: If you know where it's ending?

LEE: Then you don't have to worry about that. And, of course, we're talking about a group project, right? It's an improv with people, others, so we know also that they know where they're going and we're going there together. So how we get there can really be playful.

ANTON: Maybe it relates also to the openness which comes with acceptance. Can one be too open, too accepting?

LEE: One has to know one's intention, or objective, or aspiration. 'Too open' would mean without any investment, without any sense of responsibility.

ANTON: I can't recall if you reference it directly, but the Del Close tenet of 'Yes, and..."ii comes through quite a lot in your book. There are many places where you talk about practicing 'saying yes' to life, the situation you're in -

LEE: What choice do you have? 
ANTON: Yes. I also like what you say about intention and responsibility, it made me think about 'care' and 'carefulness' or 'tending to' and 'taking care' and how that's different from control. Even 'tenderness', as taking care of other people and yourself in the process. This could also happen in allowing, not necessarily in imposing.

Could you say more about the 'gap', or the 'space', the opening into which something might emerge...?

LEE: In improv? In mindfulness? A gap is just the space isn't it? So, like with us talking to each other, we have this kind of gap.... (laughs)

ANTON: I guess it's something that can seem paradoxical or contradictory to write about, because writing is in space, but the time of reading is asynchronous, so there's already a gap there, whereas performance is in time. So one requires a space in time for something to emerge. I find it quite difficult to leave a gap - even in this conversation - because I want to grasp at explanations.

LEE: Yeah, yeah. Exactly. We all either want to press our point, or not bore the audience, or make sure that something exciting is going to happen, or that we have something to say. But things don't change unless there's an opening...So the 'gap' first comes up in practice when you begin to see a separation between the thinking and your mind.

ANTON: Okay, that's a big one.

LEE: It's the same thing though. You have to practice before you can do it in public. It's got to be some kind of personal acceptance of emptiness.

ANTON: Because we relate thinking to our mind, or we identify with it, we think 'that's me, it must be my thoughts'.

LEE: Yeah, we have a great investment in thinking that we exist.

ANTON: (laughs)

LEE: (laughs)

ANTON: Thinking, therefore we are. Have you have you heard of the South African concept of ubuntu? It's the tenet of 'I am because of other people', rather than 'I think, therefore I am'.

I think what really drew me to Chögyam Trungpa was his interest in the 
arts and creativity. A lot of Tibetan lamas who came over weren't all that interested in Western arts and ways of thinking, whereas he seemed curious. It felt more like an act of integration than propagation.

It must have been quite remarkable to know him and to learn directly from him.

LEE: I agree. Amazing.

ANTON: How many years did you know him?

LEE: He died in 1987, and I met him in 1973. But, you know, those sort of things don't necessarily have beginnings and endings. In terms of studying meditation and Buddhism and Dharma and art, it's all kind of the same thing.

ANTON: What do you think imprisons performers, or meditators or creative people? What prevents openness, confidence, ease? What prevents compassion and kindness and the wish to help others? What is trapping people?

LEE: Well, I think we both know the answer.

ANTON: The three poisons?
LEE: Sure, the three poisons, and what causes them?

ANTON: Grasping or clinging to self?

LEE: Yeah, don't you think?

ANTON: Seeing the self as solid?

LEE: I think it's fear, I think it's an inheritance, and we just haven't learned beyond that stage of growth.

ANTON: We're living in quite fearful times; the currency of fear is rampant.

LEE: I think so. But Trungpa Rinpoche was always seeking to fill the pimple, so that it could be popped.

ANTON: (laughs) Fill the pimple? What does that mean?

LEE: Well, as long as it's kind of festering under the surface, there's not much you can do to get rid of it; but if you can let it come to a head, it can burst, and then it can be cleansed.

ANTON: Does theatre have a place in that - bringing things to a climax? What you describe sounds like a kind of catharsis. 
LEE: It does sound like that, in a Western way. Rinpoche was very strong in feeling that arts - and theatre as one of the arts has a role to play in helping the West to come to a clear understanding of the nature of reality.

The study of theatre could be seen as a way to elevate the understanding of each person, or it could be that the show is a way to teach an audience... I think I chose the route of training performers about Dharma through theatre.

ANTON: Rather than making 'Buddhist Shakespeare'?

LEE: Yes, exactly.

ANTON: I often think that remarkable Avant Garde get together that Trungpa hosted in 1973 may have sparked a seed that revolutionized modern theatre. If you think of the people who were there and what they went on to do. Okay, maybe they were already edgy before, but every single person there, like Robert Wilson, went on to do incredible things; and yet nobody seems to know about that intervention in academic theatre departments today, or consider that something astonishing might have happened there.

Maybe it's because people are wary of religion, or the concept of 'Buddhism'. So if you were to say - I want to make 'Buddhist theatre', it would make folks think you're proselytizing or something, but the Dharma is bigger than Buddhism.

LEE: Buddha wasn't a Buddhist.

ANTON: I feel like I've been talking a lot from my side, is there something you want to say that I haven't given you space to say?

LEE: I wanted to get a clearer understanding of how you're using the word 'improvisation.' I always think that everything is an improvisation, even if there's a script attached. Certainly with the Open Theater, it was very visceral, with sound and movement, but still communication happening. I don't really know what we're looking at in terms of improvisation.

ANTON: I thought an interesting question might be: what is not improvisation?

LEE: Yeah, good way to look at it. 
ANTON: In one of the articles I was reading about jazz, they talk about 'the law' as something that is set, that you don't want to be improvised. Rules. And in some way ritual and tradition and replication or repetition are things that are continuous, or that are put forward as permanent. But, certainly in a lot of these books l've been reading on improvisation, it does come up that, well, evolution is improvisation, and learning is improvisation, and improvisation is life, or could be seen as a way of life.

I've been reading this wonderful book by Steven Nachmanovitch, The Art of Is, where he talks a lot about this. He does have a Dharma inclination, and he sees improvisation as a life force or energy that can be cultivated or encouraged.

I suppose a lack of improvisation could be found as 'stuckness', in stereotypes and cliches. Certainly, a lot of folks in theatre, like Peter Brook, talk about improvisation in their training, or as part of their work with scripted works, with Shakespeare or whatever. There it can be helpful as an exercise; and yet there is a difference, I think, in presenting improvisation itself as performance, as an art form. One of the definitions that comes up involves the audience being present at the act of creation. Content is created in front of an audience, so they see this actual moment of spontaneous generation of music, speech or movement - something which has never been notated or tabulated before emerges, arises in their presence.

And this can create an excitement in the audience, because there's a huge risk involved. There's nothing to fall back on in terms of choreography, text or musical notation. It also seems as though we've moved into an era which lacks improvisation. For example, I was amazed to read in Nachmanovitch's book that for Beethoven, Bach and Mozart, improvisation was absolutely normal. It was a standard that part of any concert would be improvised. And then at some point, (probably sometime in the Augustan Age of Reason and the rise of science and so forth), the tradition changed and experts said: 'No, we need to tie down these notes. This is how you play it properly and I'll smack your fingers with this ruler if you're playing the wrong note or using the wrong finger'. So that was something that was imposed onto the classical tradition. Improvisation was curtailed. l'd be curious at looking at what was imposed on art to stop it from being improvised. Possibly it's the rise in importance of 'the text'. 
LEE: Are you saying that if you're doing the same form a second time it's not an improvisation?

ANTON: I think in terms of what's understood today, if you sold a performance as an improvised show, yes, one would assume the content hadn't been created in advance, and the audience would be witnessing the moment of creation.

LEE: But isn't part of the craft of theatre that exact thing. Every night? First of all, it's a fresh audience. Second of all, it's a fresh day. Everything has changed since yesterday. If that isn't considered as part of improvisation, then it continues to just be kind of random. But if it's something that can truly emerge, not necessarily a replica of what emerged last night, but something this night. It seems unfair to expect that improvisation is limited only to things that are only going to happen once.

ANTON: I guess if you look at the performer as creator - Artaud and Grotowski et al - then they are improvising and creating and making discoveries in the moment. What's not improvised is the text or the notation.
LEE: Right. And the building and the lights. Although the lights could be improvised also. I guess my point is that the word should be expanded to accept that 'the moment' can always be improvised regardless of whether it's onstage or offstage.

ANTON: That's true. Well, with this issue of the journal we're casting the net wide and opening up the concept of 'improvisation' in many different guises, so we'll see what people want to bring to the table... Thanks so much for talking to me, this was really interesting.

LEE: Thank you. It was very enjoyable to be with you and nice to see you.

ANTON: Have a great day.

${ }^{\mathrm{i}}$ Publication forthcoming (Journal of Performance \& MIndfulness, Vol. 4, Issue 1, 2021).

ii Close, D. et al. (1994). Truth in Comedy: The Manual for Improvisation. Chicago: Meriwether. 